\title{
The latest Turkish-Greek détente: instrumentalist play for EU membership, or long-term institutionalist cooperation?
}

\section{H. Tarık Og`uzlu}

To cite this article: $\mathrm{H}$. Tarık Oguzzlu (2004) The latest Turkish-Greek détente: instrumentalist play for EU membership, or long-term institutionalist cooperation?, Cambridge Review of International Affairs, 17:2, 337-354, DOI: 10.1080/0955757042000245933

To link to this article: https://doi.org/10.1080/0955757042000245933

Published online: 21 Oct 2010.

Submit your article to this journal $\sqsubset$

Џ Article views: 99

Citing articles: 1 View citing articles 5 


\title{
The Latest Turkish-Greek Détente: Instrumentalist Play for EU Membership, or Long-Term Institutionalist Cooperation?
}

\author{
H. Tarık Oǧuzlu \\ Bilkent University
}

\begin{abstract}
The recent thaw in bilateral Greek-Turkish relations is promising, yet insufficient for future stability and cooperation in and around the Aegean Sea. The main reason lies in the prevalence of instrumental-strategic thinking on the part of both states. Neither Greece nor Turkey has approached the settlement of their disputes from a perspective that would imply an eagerness to build a collective identity based on the institutional norms of European international society as represented by the European Union. On the contrary, Europeanisation has not been an end in itself but a means for the materialisation of their preconceived national interests. The underlying motivation behind their attempts to reach a solution appears to have arisen from instrumental concerns vis-à-vis both the EU and each other. The dynamics of their independent relations with the European Union seem to have compelled them to come to a modus vivendi over these issues, since otherwise their relative status vis-à-vis the EU would likely deteriorate. This article will discuss the main aspects of the latest Turkish-Greek cooperation process within the framework of rationalist instrumentalist and sociological institutionalist debate in international relations theory. It will be contended that a lasting and long-term cooperation between the two countries can only follow the formation of collective identities and common national foreign policy interests, particularly as they relate to the European Union framework.
\end{abstract}

The recent thaw in bilateral Greek-Turkish relations is promising, yet insufficient to ensure future stability and cooperation in and around the Aegean Sea. In the middle of 1999 , the two countries set into motion a cooperative interaction process and since then have succeeded in sorting out several thorny issues. Not surprisingly, the main platform on which they have undertaken this painful exercise has been within Turkey's EU accession process and Greece's efforts to catch up with the latest stage of EU integration.

Taking stock of this double Europeanisation process, many observers have concluded that it is irreversible, and as long as both states preserve their aspirations to further 'Europeanise', neither the Cyprus dispute nor the larger Aegean issues will remain unsolved. In parallel to their internalisation of European identity, as represented by the constitutive norms of the European Union, this view anticipates that the two states will end up developing similar and harmonious national identities and foreign policy interests. Sooner or later, a lasting settlement on these issues will ensue, since their continuation would 
hamper both Turkish and Greek desires to become true Europeans and take their seats around the same EU table in Brussels. ${ }^{1}$

However, this article will argue that there is insufficient basis for this degree of optimism. The main reason lies in the prevalence of instrumental-strategic thinking on both sides. Neither Greece nor Turkey has approached the settlement of their disputes from an ideational perspective. Neither of them, particularly Turkey, considered the resolution of the Cyprus and the Aegean Sea disputes as a legitimate or required step, and instead they have pursued the process only to fulfil the EU's requirement that such steps be taken as a predicate for confirmation of membership in the European international society. As such, they appear to have invested in the idea that resolving these disputes is necessary within the dynamics of their relations with the European Union, even though in their view it does not necessarily represent the norms of the more general European international society. Their relations with the European Union therefore, seem to have compelled them to come to a modus vivendi over these issues, since otherwise their relative status vis-à-vis the EU would likely deteriorate. Hence, the underlying motivation behind their attempts to reach a solution appears to have arisen from instrumental concerns vis-à-vis both the EU and each other.

Against the background of the argumentative logic used by both states, this article will first analyse the main theoretical approaches for understanding the complexities of Greek and Turkish thinking over the past four years. There follows a discussion of the main reasons why the latest Turkish-Greek détente appears to have led some observers to view the latest reconciliation process as holding promise for the future. Before concluding, the article will analyse the underlying reasons why the latest détente in bilateral relations is fragile. It will be argued that unless the existing instrumental logics are replaced by more ideational concerns on the part of Greece, Turkey and the EU, and unless Turkey and Greece develop similar national identities and foreign policy interests within the framework of the Europeanisation processes, they will compromise any chance at resolving their territorial disputes for a long time to come.

\section{A Theoretical Framework}

Turkey and Greece have been experiencing a cooperative period in their bilateral relations since 1999 following the confirmation of Turkey's EU membership candidacy. The EU's offer of candidacy, Greece's agreement to Turkey's new status and Turkey's acceptance of the EU's offer can be seen as an example of interstate cooperation. However, the question is whether this cooperation and the ensuring Turkish-Greek reconciliation efforts have occurred as a result of strategic-instrumental factors based on material cost-benefit calculations, or ideational factors representing the will of the parties concerned to share common identity and foreign policy interests. This is significant, for strategic action would lead to conjectural and temporary cooperation while ideational action would imply long-term cooperation.

\footnotetext{
${ }^{1}$ The main reason behind the optimism of these circles has been the dynamics of the EU's enlargement process, which should dictate cooperative neighbourly relations among candidate and members states.
} 
The situation can be analysed from two different vantage points: rationalist institutionalist or sociological institutionalist. A rationalist institutionalist theory posits that states cooperate out of domestically formed national interests and comply with the terms of cooperation as long as they believe that doing so can serve their interests (Mearsheimer 1990; 1994/95). Here, regional institutions, the European Union in this case, are nothing more than embodiments of the national interests of member states (Duffield 2002). They do not have a life of their own independent of the states that constitute them. Decisions whether to enlarge or not are based on the outcomes of intergovernmental bargaining processes among members states. Most of the time, economic and security considerations loom in the background, shaping member states' preferences for enlargement (Sjursen 2002, 491-513). In this scenario, even though pro-enlargement members try to justify their materially formed national interests on the basis of the EU's common identity and values, their decisions are taken for instrumental reasons and continue to be valid only for as long as the prospect of material gains figure in the future (Schimmelfennig 2000; 2003).

Instrumental decisions in favour of enlargement acquire legitimacy therefore only if additional grounds can be found for their justification in the eyes of EU members that are reluctant to see the EU enlarge. For example, in the case of the EU's enlargement towards the Central and Eastern European countries (CEECs), the decision to enlarge was more easily justified and legitimised in light of the moral, cultural and ethnic affinity that could be drawn between many of the member states and the majority of the CEECs, which made it easier for the pro-enlargement lobbies within the EU and aspirant states to convince the sceptical sections of their publics of the benefits and appropriateness of the move (Schimmelfennig 2001).

From a rationalist institutionalist approach, the EU would not need to appear to be a postmodern and post-national security community, for what brings the member states together is the convergence of their individual national interests. Aspirant states comply with the membership criteria imposed by the EU in a hierarchical way, because their expected material benefits from future membership would outpace the short-term costs of the accession process. This does not imply that cooperation out of material interest is negative. However, in the absence of strong cultural, moral and ethnic links between the EU on the one hand and an aspirant state on the other, the accession process becomes problematic, for the rewards of membership are less consistent, and the costs perhaps larger, leading the aspirant state to show less ideational commitment toward membership. For example, when the EU shapes its enlargement policies on the basis of purely instrumental and material grounds, aspirant states would likely doubt the real motives of the EU and thus hesitate to implement the membership criteria in earnest (Rumelili 2003; 2004).

From this perspective, institutional affiliations only serve as the means for states to realise their own interests (Waltz 2000). As a result, Greece would try to gain advantage over Turkey through its full membership in the EU, whereas Turkey would form its policy towards Greece as a derivative of its relations with the EU. The more Turkey would aspire to join the EU, the more conciliatory it would become towards Greece. Under these conditions, the European Union would not serve as a platform for bringing Turkey and Greece closer in terms of their real identities and interests. Instead, Greece might try to increase its 
bargaining power vis-à-vis Turkey by emphasising Turkey's non-European character; and Turkey might try to counterbalance Greece by painting Greece as a weak and marginal country within the EU, one incapable of damaging the smooth functioning of Turkey-EU relations.

The sociological institutionalist view, on the other hand, interprets the European Union as a postmodern/post-national international entity with a logic of integration and expansion based on the idea that it is a supranational entity with a membership that first and foremost comes together around collectively shared norms and rules and that it should encompass other states in order to reconstitute its identity and legitimacy in the eyes of the international community (Smith and Timmins 2000; Winn 2001). Decisions to enlarge or to grant candidacy status would be based on identity and legitimacy, rather than on purely material interests. The European Union would not view outside states from a self-other perspective, defined in terms of cultural and ethnic terms, but would radiate its norms by offering them credible membership prospects (Manners 2002). In this view, any European country would sooner or later join the EU once it met the accession criteria and internalised the EU's constitutive norms and identity. Turkey and Greece would more easily cooperate and solve their territorial disputes, and they would each approach the EU from an ideational perspective instead of an instrumental one. The socialising capacity of the EU would increase under such conditions because the EU would be vested in promulgating its norms to candidate countries lest its own self-identity face a legitimacy crisis.

From a sociological institutional perspective, therefore, Turkey and Greece might be expected to cooperate within the framework of the European Union, because of a need to emphasise that they share (and are eager to internalise) the constitutive norms of the European Union. Further, because being true Europeans implies having peaceful bilateral relations, it would be legitimate and appropriate for them to solve their territorial disputes in a peaceful way.

In this case, neither Turkey nor Greece would try to justify their European identities by referring to the non-Europeanness of the other. Greece would support Turkey's EU membership not because it would gain instrumental benefits while Turkey strives to meet the accession criteria, particularly concerning Cyprus and the Aegean Sea, but because the security identity and interests of the postmodern/post-national European Union would dictate Turkey's full membership in the EU. In turn Turkey would find it legitimate to solve its disputes with Greece within the EU framework and would not think that Greece backs Turkey's membership aspirations out of instrumental and tactical considerations.

Based on this theoretical account, the following section tries to answer whether the Turkish-Greek cooperation process of the last four years has been built on the logic of sociological institutionalism or instrumentalist institutionalism.

\section{Why Promising?}

The latest Greek-Turkish rapprochement since 1999 appears in some ways to be different from previous periods of cooperation and détente. The following section will analyse why the latest cooperation process seems to possess the 
potential of leading these two countries to cooperate on the basis of emerging collective identities and interests.

First, the new thaw in bilateral relations has strong domestic public support. Compared with the past, when public opinion generally constrained political leaders from taking bold initiatives, the new era has witnessed the majority of both the Greek and Turkish peoples supporting the current reconciliation process (Heraclides 2002). The reasons behind this public swing are twofold. First, both nations felt empathy toward the other when each was struck by a devastating earthquake. Further, the Greek public experienced a severe shock when their country's international legitimacy was tarnished by their government's mishandling of the Ocalan asylum crisis.

Second, adding to public support, most political leaders in both countries favour closer cooperation. Both PASOK (Panhellenic Socialist Movement) and the New Democracy party in Greece support the reconciliation process. It is getting more and more difficult for the political parties to get votes by strictly adopting a nationalistic discourse. Further, democratisation, particularly in line with the Europeanisation process in both countries, holds out the prospect of decreasing the appeal of more nationalistic and more unilateral policies to the public. This trend might lead both countries to adopt the EU's favourite means of conflict resolution, namely the processes of politicisation and de-securitisation (Waever 1997)

Third, business elites in both countries have encouraged their political leaders to mend fences. Bilateral trade volume has increased at least threefold over the last three years, showing the degree of support the business circles give to the cooperation process (Larrabee and Lesser 2003, 87). The activation of the Greek-Turkish and Turkish-Greek business councils in 1998 and the increase in the number of joint ventures and investments indicate that the stakes for the business elites in the cooperation process are getting higher. In 2001, cross-border trade jumped to an estimated US\$1 billion from US\$700 million the previous year. Yet, because Turkey still accounts for less than 5\% of Greece's trade balance, there is significant potential for increasing trade (Hope 2001). If the volume of these bilateral economic activities increases without interruption, it would be difficult for future political leaders to reverse this process. The creation of the Turkish-Greek academic forum in 1998 and the effort by both nations to implement various confidence-building measures, such as stopping military exercises during the summertime, have also been positive.

Fourth, the current Turkish-Greek cooperation process seems to be operating in accordance with a functional approach. As outlined by David Mitrany (1966), cooperation in economic and technical spheres is easier than cooperation in security or political areas because states can develop joint interests in the former more comfortably. It does not matter that states end up having supranational institutions. What matters is that their cooperation in political and security issues becomes higher if they have already developed a cooperative relationship in technical issues. Thus, instead of focusing exclusively on the resolution of hard security issues in the short run, the leaders of both countries have actively supported the view that cooperation should first continue in areas of low politics (economic and cultural). The hope has been that the more cooperation increases in the areas of low politics, the more difficult it would be for political leaders to put the gains of this process into danger by adopting intransigent and unyield- 
ing approaches towards the resolution of the more thorny issues of high politics (Heraclides 2002, 18). Since 1999, both countries have signed more than ten treaties regulating terrorism, immigration, energy transportation, environment, de-mining, illegal drug traffic, tourism, fisheries, education and sport. ${ }^{2}$ Half of these agreements were signed in Ankara when the Greek Foreign Minister George Papendreou paid a historic visit to Turkey on 19-22 January 2000, the first such visit in three decades. The other half were signed in Athens during Turkish Foreign Minister Ismail Cem's visit on 1-3 February 2002.

Both countries have initiated consultation on issues of high politics as well. Since early 2002, diplomats from both foreign ministries have exchanged views on disputes concerning the continental shelf and territorial waters. It is a good omen that the steering committees that prepared the treaties on the issues of low politics have not been dissolved, and that the Task Force that was established to channel Greece's experiences and know-how to Turkey in its efforts to adopt the EU's Community Law is still functioning.

Fifth, the Greek national strategy has evolved in such a way that the majority of the Greek political and military elites are today in favour of Turkey's closer relations with the European Union (Tsakonas and Tournikiotis 2003). Greece's national interests can be understood to accept Turkey's further anchoring to the European Union because this seems the only way to settle territorial disputes in the name of further Europeanisation. The old strategy of 'conditional sanctions' has given way to a new strategy of 'conditional rewards'. Instead of threatening to veto Turkey's EU membership unless the latter supports a more pro-Greek settlement over the Aegean Sea and Cyprus disputes, the new Greek strategy implies active support of Turkey's membership should the latter show more accommodating and cooperative stances over the bilateral disputes (Couloumbis 1999). This new Greek policy is promising because the materialisation of Greece' national interests requires both the resolution of Turkish-Greek territorial disputes and the continuation of Turkey's EU accession process. Further, it is based on positive incentives rather than negative conditions. Greek politicians have become aware that the road to peace in the region passes through the further Europeanisation of Turkey and the resolution of Turkish-Greek disputes. The hope that a Turkey that is more Europeanised and democratised would be more peaceful and cooperative in its foreign policy appears to underpin the essence of the current Greek strategy (Tsakonas 2001).

Sixth, Turkey's perception of Greece's relative position within the EU has started to change in the second half of the 1990s in such a way that the Turkish elite now see that the dynamics of Turkey-EU relations have been strongly affected by the tone of Turkey-Greece relations (Guvenc 2000). The Turkish political elites have gradually embraced the view that Turkey also has to come to terms with Greece over the Aegean and Cyprus disputes if it wants to join the EU. Greece is now being considered very seriously by Turkey. The more Europeanised Greece becomes, the more difficult Turkey is finding it to rely on major EU members to pressure Greece to stop putting obstacles in Turkey's path to Brussels. This has been an outcome of Greece's efforts at Europeanisation, which gained momentum with the ascendancy of the Kostas Simitis government

\footnotetext{
${ }^{2}$ One can see the content of these treaties on the webpages of the Turkish and Greek foreign ministries: < http://www.mfa.gov.tr $>$ and < http://www.mfa.gov.gr $>$.
} 
in 1996. Simitis's government reasoned that the success of Greece's further Europeanisation process would strongly be tied to its cooperative relations with Turkey. Since then Turkey's perception of Greece's role in overall EU-Turkey relations has started to change.

Seventh, Turkey's interest in EU membership has increased in the postHelsinki period, particularly following the September 11 events (Oguzlu 2002a). Turkey's political Islamists have made a U-turn and decided to support the accession process. Even though many claim that their prime reason for this change has been to find an external ally against the well-established state elites within the country, the fact that these circles constitute nearly one-third of Turkish society is significant (Oguzlu 2003). Additionally, the stakes of exclusion from the EU, particularly on cultural and civilisational grounds, are being seen as much higher today than in the past. Turkey has therefore speeded up its efforts to meet the accession criteria. A significant motivator in Turkey's interest in EU membership is its concern not to have to engage with the United States on a purely bilateral level. Turkey hopes to increase its bargaining power vis-à-vis the US by approaching it via the European Union. Given that USTurkey interdependency is skewed in favour of the former, a weak, non-Europeanised Turkey is less able to stand up to American demands. An interdependent EU-Turkey relationship would serve to balance the scales somewhat, enabling Turkey to pursue its interests more effectively. Yet, for this to happen, Turkey needs to become more Europeanised and to adopt the EU's security identity. Otherwise dependency on the United States will likely increase, while Washington will possibly find that dealing with Turkey becomes increasingly awkward (Oguzlu 2004a). Given NATO's increasing difficulty in bridging the two sides of the Atlantic, remaining outside the EU would mean that Turkey's institutional standing with those EU partners inside NATO would negatively impact on Turkey's Europeanness (Oguzlu 2002b).

A major concern for Turkey has been Cyprus. Turkish foreign policy makers realised that if Cyprus joins the EU a divided island, its impact on Turkey's relations with the EU could be catastrophic. Greek Cypriots will likely demand radical concessions during the accession process, and make it more difficult for Turkey to achieve membership by blocking Turkey from within the EU (Oguzlu 2002c). That is why the current government supported the resolution of the Cyprus dispute within the framework of the United Nations Secretary General Kofi Annan's plan.

To this end, the Turkish Parliament has recently passed several radical laws, such as curbing the role of the military in the political arena and improving the sociopolitical status of citizens of Kurdish origin in Turkey. Furthermore, in 2002, the security establishment of the state rewrote Turkey's National Security Policy Document, which for the fist time did not mention Greece as the top external threat to Turkey's national security (Cizre 2003). These changes are aimed at adapting Turkey's internal and external make-up to those of the European Union. Reflecting this new mood, even the former Vice Chief of the General Staff argued for Turkey's EU membership on strategic security grounds claiming that Turkey's accession to the EU is a geopolitical necessity. ${ }^{3}$

${ }^{3}$ The speech of Second Chief of Staff, Yasar Buyukanit, in the Conference on Globalisation and Security, organised by the Turkish War Academy on 29-30 May 2003. 


\section{H. Tarık Oğuzlu}

Eighth, the European Union and the United States actively support the current cooperation process for their own security reasons. It can even be claimed that bilateral moves are becoming institutionalised through Turkey's EU accession process. Critical in this regard is the change in EU policies towards Turkey (Brewin 2003). Since 1999, Turkey has been tapped as an official candidate for EU membership, based on the same criteria as applied to other would-be members. As doubts about Turkey's European identity evaporate, Turkey is being increasingly encouraged to settle its disputes with Greece within the EU framework.

The Americans are also encouraging the latest Greek-Turkish rapprochement in the hope that Turkey's EU membership prospects increase with the settlement of their disputes. To US politicians, Turkey's pro-Western and pro-American orientation will be bolstered if Turkey joins the EU. A more European and Western Turkey would more easily and likely cooperate with the US in the realisation of the latter's strategic security interests in the greater Middle Eastern region (Kuniholm 2001).

Ninth, a strong reason to become optimistic about the future of TurkishGreek relations is that these two countries have gradually developed the habit of cooperation over the last four years. Below is a summary of the cases of cooperation.

Since the first Turkey-Greece EU Committee meeting in February 2000, Greek officials have offered training to their Turkish counterparts on customs and financial issues, judicial reform, agricultural issues, and law enforcement concerning illegal immigration, narcotics trafficking and organised crime in the region (Hercalides 2002).

In early 2001, both countries agreed to eliminate the landmines on their common borders over the next ten years. They also simultaneously became signatories of the 1997 Ottawa Convention requiring the destruction of existing landmines and prohibiting future landmine use and production (Heraclides 2002).

In early 2001, Greece lifted its state of mobilisation for war against Turkey. Turkey is no longer officially considered the prime threat to Greece. In addition, in mid-2001 the militaries of both countries announced a downsizing in their military spending. Even though the decision of the Turkish military authorities was prompted by an economic crisis, the Greek authorities anticipated this development and announced that they would also go for savings (Brauer 2002).

In early 2001 the two countries agreed to cooperate on a feasibility study under the EU's INOGATE (Interstate Oil and Gas Transport to Europe, An EU-funded program) programme for a series of pipelines to carry natural gas from Central Asia to Europe. The US $\$ 10$ billion project would bring interconnections between the Greek and Turkish networks. In addition, in the spring of 2002 they agreed to build a cross-border pipeline to carry natural gas from Central Asia to Western Europe. The 177-mile pipeline, expected to cost US\$300 million and take three years to build, would be the first joint infrastructure project launched by the two neighbours and is the first intergovernmental project to take practical shape (Hope 2002).

(Footnote continued)

See: < http://www.tsk.mil.tr/genelkumay/bashalk/konusma/sarem/saremaciskonusmasi_290503.htm $>$. 
In early 2002, the two foreign ministers, Papandreou and Cem, achieved a political breakthrough when they agreed that Greek and Turkish experts should start talks on a series of long-entrenched bilateral disputes, such as airspace over the Aegean Sea and ownership of mineral rights in the seabed. If agreement cannot be reached, the aim is for the two countries to jointly refer these issues to the International Court of Justice at The Hague (Heraclides 2002).

The two nations' cooperation within the NATO framework has also improved. In July 1997 they signed a memorandum of good-neighbourly relations on the margins of NATO's Madrid summit, at which time the Alliance officially endorsed the primacy of the Eastern Mediterranean region. Greece and Turkey came to an agreement over NATO's command structures in December 1997. Before Greece's withdrawal from NATO's military structure following Turkey's military operations in Cyprus in 1974, the two countries shared NATO's command responsibilities in and around the Aegean Sea in a non-problematic way. Following Greece's withdrawal from NATO, Turkey demanded a reformulation of NATO's command and control responsibilities in the region, based on the view that the pre-1974 arrangement favoured Greece. When Greece applied to re-enter the Alliance in the late 1970s, Turkey insisted that the command and control issues be sorted out prior to Greece's re-admission. Greece, on the other hand demanded that it be handled afterwards. Following the 1980 military coup in Turkey, the new government acquiesced to Greece's re-entry into NATO, at the Americans' nudging, even though no satisfactory agreement had been reached. Until 1997, the issue of NATO's command and control responsibilities in the region remained ambiguous (Veremis 1988). This changed in the summer of 1998, when both countries agreed to revitalise the Confidence Building Measures, to which they had agreed in 1988. In September 1998 they agreed to the establishment of a Balkan regional peacekeeping force, and both cooperated in NATO's war in Kosovo in 1999. Greek and Turkish soldiers for the first time since 1982 participated together in a NATO military exercise in May 2000, called Dynamic Mix (Papacosma 1999).

\section{Why Fragile?}

Despite all the promise of the above achievements, other factors have the potential to render the latest Turkish-Greek cooperation process fragile. These indicate that neither Turkey nor Greece can easily escape from a strategic instrumentalist approach. A brief historical review will highlight patterns that continue to be followed today.

Until 1999, the main assumption behind Greek policies was that it would feel more secure and safe if Turkey remained outside the EU for ever. From the time Greece joined the EU in 1981 until the second half of the 1990s, the majority of the Greek political parties converged on the foreign policy goal of keeping Turkey out of the EU's orbit and of confirming Turkey's non-European character to those within the EU (Coufoudakis 1991). To this end, the continuation of the no-solution situation in the Aegean Sea and Cyprus served Greece's interests by driving wedges between the EU and Turkey. There was almost no serious commitment to the resolution of those disputes, so long as their non-settlement helped Greece erect barriers to Turkey's membership. Between 1982 and 1986, 
Greece tried to obstruct the reconvening of the EU-Turkey Association Council, which was suspended by the EU following the 1980 military coup in Turkey. The then Greek government tried also to prevent the flow of financial aid to Turkey mandated by the requirements of the Fourth Financial Protocol signed between the EU and Turkey in 1981. In light of the EU's ambiguous attitude towards Turkey, Greece easily justified its anti-Turkey policies. For some time, the main way for Greece to improve its European identity within the EU consisted in its attempts to throw doubt on Turkey's Europeanness (Tsoukalis 1999).

Against this anti-Turkish profile, it has gradually become more difficult for Turkish politicians to believe that Greece has really changed its perception and since 1996 has been acting on the basis of a new cooperative logic. The legacy of the first two decades of Greek membership in the EU is not easy to dismiss.

Moreover, Greece's strategic rationale for supporting Cyprus's EU membership and the Joint Defence Doctrine of late 1993 were also perceived as anti-Turkish expansionist and irredentist threats (Stivachtis 2002). Turkey's behaviour towards Greece, meanwhile, reflected the assumption that whatever accommodating moves it made over the Aegean Sea and Cyprus, the EU would still never agree to its membership due to other factors. Turkey's main rationale was that if the major members of the EU were convinced of the merits of Turkey's accession to the EU, then the Cyprus and the Aegean Sea disputes would not be major factors affecting Turkey's membership prospects. The Turkish hope was that the EU would put pressure on Greece not to veto this process (Guvenc 2000).

Turkish elites, moreover, have developed the attitude that the more the EU approaches Turkey's membership positively, the more Turkey can accommodate Greek claims over Cyprus and the Aegean Sea (and not the other way around). This harkens back to the early 1990s, when Turkey's prospects for joining the EU declined with the emergence of identity politics in the EU's enlargement policies. Concessions to Greece over the Aegean Sea and Cyprus were viewed as implying strategic losses for Turkey in the region, rather than increasing its chances of EU membership. Based on the fear this engendered, Turkey gradually came to counter the Greek strategy of 'conditional rewards' with a strategy of 'conditional sanctions': any difficulties prompted by Greece in Turkey's relations with the European Union would affect the peaceful atmosphere in the Eastern Mediterranean region, negatively impacting on Greece's ability to complete its own 'Europeanisation process' (Onis 2001; Kramer 1999).

Due to divergence of opinion on how to handle the crises in the Balkans, Greece and Turkey set off a chain of rivalry reflecting their desire to dominate regional politics in the post-Cold-War era (Turan and Barlas 1999; Buyukcolak 2000). Despite both being members of the Western security community, they elected not to cooperate within the structure of their institutional links with the West. Instead, they supported opposite sides: Turkey sympathised with the Muslims in Bosnia and Kosovo; Greece backed the Orthodox Serbians (Bahcheli 2000). Interestingly, while Greece's Balkan politics in the first half of the 1990s were mainly nationalistic, unilateral and anti-Western, Turkey's reflected a multilateral, pro-Western, cooperative dimension. The Turkish-Greek rivalry in the Balkans was based mainly on Greece's fear of encirclement in the face of Turkey's warm relations with its neighbours (Ioakimids 1999).

Turkish-Greek conflictual relations in the 1990s have expanded in other 
ways. Three separate crises in the Aegean region indicate how vulnerable, and even dangerous, the situation is. First, a serious crisis broke out in February 1996 over the legal status of two small islets in the Aegean Sea situated three miles off the Turkish coast, called Kardak to the Turks and Imia to the Greeks. In fact, the two countries almost came to war over the issue (Hickok 1998). The significance of this crisis lies in the fact that Turkey for the first time questioned the legal status of various islands scattered in the Aegean Sea and coined the term 'grey areas' to bring the issue of their sovereignty onto the agenda. More ominously, the Imia/ Kardak crisis revealed that if the ongoing democratisation process in Turkey is not seriously supported by the European Union in such a way that it backs pro-democracy and pro-EU circles, then democratisation may benefit only the circles that thrive on parochial and unilateral nationalism (Oguzlu 2004b). The performance of Prime Minister Ciller of the True Path Party confirmed this. She adopted a highly nationalistic approach and did not hesitate to warn Greece of the dire consequences it could expect if it did not withdraw its soldiers and flag from one of the Imia islets. An ambiguous EU policy towards Turkey's accession, therefore, would enable its political parties to employ mobilising ideologies of 'nationalism' and 'political Islam' (Adamson 2002).

The second crisis took place when the Republic of Cyprus expressed its intention to bring in S-300 surface-to-air missiles from Russia. Turkey and the Turkish Republic of Northern Cyprus jointly declared they would strike at the missiles if they were installed. Although tensions abated once the Greek government decided to place them instead on the island of Crete, the implication that Turkey was an enemy that needed to be countered through military build-up, which had dictated the policy of ordering such surface-to-air missiles in the first place, still prevails (Yiallourides 2001).

The third crisis arose with the involvement of Greek agents in the apprehension of Abdullah Ocalan, the leader of the outlawed PKK (Kurdish letters for the Kurdistan Workers Party) terrorist organisation. For the first time, the Turkish accusation that Greece had been giving support to the PKK was given credence when it became public that Ocalan was sheltering in the residence of the Greek ambassador in Kenya. This crisis in bilateral relations was partially resolved with the ouster of Teodoros Pangalos, the Greek Foreign Minister, from the cabinet. Soon after, the new Greek Foreign Minister George Papandreou agreed to meet the Turkish Foreign Minister in New York in June 1999 and then set into motion a new reconciliation process (Prusher 1999)

\section{Strategic Instrumental Thinking on the way to Helsinki}

It has been argued that Turkey and Greece launched a new cooperative process in the middle of 1999 and then crowned it by agreeing to the terms of the EU's Helsinki summit conclusions because both believed in the legitimacy of a lasting settlement in an age of globalisation. In this view, the so-called 'seismic diplomacy' has shaken up the old confrontational logic. However, Turkey's cooperative mood towards Greece can be seen to have a utilitarian intent. It can be argued that it was driven not by an underlying desire to resolve the long-standing Turkish-Greek disputes but to enhance its prospects of EU membership by taking advantage of the changing dynamics of the regional environment in 1999 and ameliorating its image in the eyes of the major EU members (Siegl 2002). In 
other words, relations with Greece have been instrumentalised in order to accelerate Turkey's EU accession process. The impact of the Ocalan affair on Greece, combined with the EU's inability to forge a common foreign and security policy in Kosovo, created an international strategic environment suitable for Turkey to act based on a cooperative logic. The thinking was that both Greece's and the EU's bargaining leverage vis-à-vis Turkey had seriously deteriorated and therefore Turkey's gains in adopting a cooperative policy towards Greece and the EU would outweigh any possible losses. Greece would have to show more flexibility towards Turkey's positions on Cyprus and the Aegean Sea in order to recuperate its tarnished image in the wake of the Ocalan fiasco. This was bolstered by the idea that taking a positive tack with Greece might better Turkey's chances for admission into the EU (Bahcheli 2000). Ankara's main motivation to cooperate with Greece therefore has not been to please the latter but rather to gain the favour of other EU members. In addition, it was considered likely that the EU would have to soften its policy towards Turkey and offer it official candidate status in order to secure its regional security cooperation (Eralp 2000). Thus by indexing the overall quality of Turkish-Greek relations to EU-Turkey relations, Turkey has approached Greece from an instrumental perspective. The more the EU has behaved receptively to Turkey's membership, the greater Turkey's conciliatory steps towards Greece. This strategy likewise has been evident in Turkey's approach to resolving the Cyprus dispute within the both UN and EU frameworks (Dodd 2000).

At the same time, Greece has approached Turkey from an instrumental perspective by viewing relations within the context of overall Greece-EU relations. The two basic Greek foreign and security policy objectives in the second half of the 1990s were (1) to improve Greece's tarnished image among it EU partners so as to enable it to join the first-tier members of the Euro-zone and (2) to enable the Republic of Cyprus to join the EU even if any a priori political settlement could not be reached (Moustakis and Sheehan 2000; Dakos 2001). These concerns were highlighted by the failure of Greece's internal balancing strategy to counter Turkey's growing power and influence in the 1990s. Greece could not match Turkey's increased military expenditures in the second half of the 1990s, and Greece's strategy of deterrence against Turkey received a setback during the Imia crisis of 1996. This was a humiliating encounter for Greece, which decided to return to the status quo ante and agreed to withdraw its soldiers and flag from the island in the face of Turkey's counter military build-up and warnings of military clashes. Diplomatically too, Greece's room for manoeuvre was constrained by American and European calls for a reduction of tensions in the region (Efstathios and Mavrides 2001). Taken together, these factors incrementally formed a single strategy toward Turkey, namely, to increase Greece's soft power through its alliance relationship with the EU.

In sum, for Greece to fulfil its two objectives, Turkey would have to be encouraged in its Europeanisation process. The hope was that encouraging Turkey's desire to join the EU would cause Turkey to adopt a more flexible attitude towards resolution of the Aegean and Cyprus disputes. And the closer the resolution of these territorial disputes became, the faster Greece would be able to join the EU's zone of peace. Otherwise, it would be difficult for Greece to accomplish its own Europeanisation project, since an alienated Turkey outside 
the EU would keep Greece occupied with territorial issues. Hence, cooperative relations with Turkey constituted a necessity for Greece to realise these goals.

The Greek policy of 'facilitative conditionality' has been based on a new discursive practice emphasising that Turkey is a European country and can become an EU member and that the EU should soon initiate accession talks. Moreover, should Turkey soften its hard line approach towards the Cyprus dispute, its chance of acceding to the EU would increase (Papandreou 2002).

Athens might hope that by initiating a new policy towards Turkey, some circles in Ankara and the EU might conclude that it was not Athens but others in the EU who were blocking Turkey's entry. A further advantage of such a policy might be that Athens would be relieved of the burdens of its armament programme. A side benefit of reducing military spending would be to free up resources that would be better applied to Greece's economic programme if the country is to achieve the EU standards put before it to join the European Monetary Union. Hosting the Olympic Games in 2004 has put further pressure on Greek authorities to downsize military spending in order to allocate more resources to this project

Greece's attitudes towards the Turkish-Greek disputes in the post-9/11 era appear to be instrumental as well. Greek foreign policy makers are aware that Turkey's strategic importance has increased and that Greece's strategic goals might be seriously endangered by an intransigent and intimidating Turkish attitude. Therefore, the Greek government has been arguing for the start of Turkey's accession talks lest the latter switch from its current cooperative stance to a much harder line. ${ }^{4}$

Despite Greece's apparent support of Turkey's EU membership, its rationale in the ESDP (European Security and Defense Policy) dispute alerted Turkish politicians to the possibility that Greece had not radically altered its exclusionary policy. While Greece has been arguing for Turkey's EU membership within the context of Cyprus's accession to the EU, it has at the same time adopted a very intransigent attitude towards the resolution of the ESDP conflict between the EU, Turkey and NATO. Greece's reaction to the Ankara deal of November 2001 offers a good example. Until the latest EU summit in Copenhagen in December 2002, in which the ESDP issue was satisfactorily resolved for all parties concerned, the Greek government appeared to act on the assumption that Turkey would never join the EU; therefore what would be the rationale of offering Turkey full rights to participate in the decision-making process of an EU-led and EU-only military operation (Missiroli 2002)? Should Greece sincerely believe in the legitimacy and possibility of Turkey's EU accession, would it have continued to derail this deal by vetoing it in previous EU summit meetings in Leaken and Seville?

\section{In Lieu of Conclusions}

The following points add further reason to view with scepticism the latest détente in Turkish-Greek relations. Unless these are considered seriously, hopes for a cooperative future might prove dim.

\footnotetext{
${ }^{4}$ It is within this context that many Greek politicians have stated that the European Union should soon start accession talks with Turkey. Interestingly, Greece has now become the most vociferous supporter of Turkey's EU membership.
} 
First, as the degree of Turkey's cooperation with Greece appears to be dependent on the nature and quality of its relations with the European Union, there is a danger is that whenever Turkey-EU relations deteriorate, the quality of Turkish-Greek cooperation might degenerate (Larrabee and Lesser 2003). If the European Union does not increase its commitment towards accession by making its intention to accept Turkey clear should the latter meet clearly defined requirements, then Turkey's democratisation process may take a different turn, resulting in a decrease in its interest in EU membership and, by association, cooperative policies towards Greece. If the EU treats Turkey as more European, only then would Greece cease to treat Turkey as non-European. In parallel to an increase in Turkey's Europeanness, Greece would gradually find it more difficult to justify its own European identity by excluding Turkey from the EU's zone of peace.

Turkey's policy towards the Cyprus plan of the UN Secretary General Kofi Annan offers a useful example. In his attempts to end the long-lasting division of the island and pave the way for a non-problematic accession of the island to the EU, Annan proposed in November 2002 a very detailed framework to the parties concerned. ${ }^{5}$ Even though many of the fundamental Turkish claims were addressed in the text, and in Annan's further revisions, the security elites in Turkey frowned on these initiatives and adopted a very cautious approach. Initially, pro-EU circles in Turkey supported the plan, hoping perhaps that even though the island would join the EU as undivided and ahead of Turkey, this would certainly strengthen Turkey's hand vis-à-vis the EU. However, these pro-solution groups, including leading figures in the ruling Justice and Development Party, eventually lined up with the more doubtful and pessimistic Eurosceptic circles. The reason for the switch appears to lie in the fact that both pro-EU and Eurosceptic circles have internalised the idea that unless the European Union offers Turkey a credible membership option that can be realised soon, Turkey's gains from EU membership of the undivided island would not compensate for its losses. This implies that the majority of the Turkish political elite has not interpreted the EU's Copenhagen summit decisions as favouring the start of accession talks. ${ }^{6}$

This reading of the situation would indicate several outcomes. First, unless the EU seriously encourages Turkey's EU accession process with credible rewards and punishments, the number and weight of pro-EU circles in Turkey could diminish, and the importance of the Eurosceptic circles could grow. This would likely result in more intransigent Turkish policies towards Greece. An additional danger is that the longer it takes for Turkey to take bold steps on these issues, the more difficult it will be for Greek politicians to rely on the encouragement of Greek public opinion. At one point, Greek politicians may revert back to courting nationalistic Greek public opinion for domestic political gain. Turkey meanwhile should reciprocate Greece's latest cooperative openings. Greece's support for Turkey's membership in the European Union and its own rehabilitation from its image as the black sheep of Europe should lead Turkish politicians to approach Greece as a normal European country acting rationally rather than emotionally (Larrabee and Lesser 2003).

\footnotetext{
${ }^{5}$ For the plan, visit the webpages of the Turkish and Greek foreign ministries.

${ }^{6}$ For the wording of the decision see the EU's website: <http://europe.eu.int $>$.
} 
Second, for the current Turkish-Greek cooperation process to yield a lasting peace in the region, the parties must address the disputes of high politics. Cooperation on issues of low politics is good, but insufficient.

Third, if the United States continues to view Turkey and its relations with Greece and the European Union from a strategic security perspective, Turkey's approach towards Greece and the European Union will likewise continue to reflect strategic and instrumental considerations. Besides, if the current intra-Alliance rift, illustrated by the US-led new Europe and German/French-led old Europe, cannot be healed soon, Turkey's behaviour towards the European Union and Greece might reflect practices of hardline realism. In the face of the division within the Western international community, it would be difficult for Turkey to line up with European stances against American ones. Not surprisingly, if Turkey always feels itself to be sandwiched between European and American choices, it will adopt more strategic and instrumental ways of thinking. Traditionally, Turkish political circles have operated as though there is one unified West and Turkey's security interests lie in close relation with this single West. If the West becomes divided, Turkey's traditional fears of 'abandonment' and 'encirclement' would resurface. The more Western powers adopt independent or different strategic visions, the more likely Turkey might be seen as an area of strategic competition, and treated as a zone of great-power competition. Under such conditions, Turkey would have to revert back to the Ottomans' practice of balance-of-power politics, which offers little guarantee of real Turkish security. A Turkey that perceives its foreign policy environment through strategic security lenses would likely interpret the developments in the region from a zero-sum mentality, highlighting costs against benefits (Oguzlu 2003).

The United States should also give active encouragement to the EU's strategy towards Turkey. This has become more important in the aftermath of September 11. If Turkey is led to expect that the new international environment provides opportunities to secure US support for hardline attitudes towards Greece and the European Union, then its incentive to Europeanise its foreign policy would decrease.

Fourth, the current Greek strategy towards Turkey should place a higher value on Turkey's membership in the EU than on the resolution of the Aegean and Cyprus disputes in pro-Greek ways. The former should be the end and the second the means, not the other way around. Turkish public opinion and the military-security elites share the view that Greece advocates Turkey's accession to the EU in general and the start of the Turkey's accession talks with the EU in particular primarily to promote pro-Greek solutions in the Aegean Sea and Cyprus. Hence, it is still not clear whether the latest Greek overture towards Turkey reflects a change of heart or could be labelled a 'change of mind' (Siegl 2002).

Finally, the interpretation of the latest Copenhagen summit by the majority of the Greek political elites does not seem promising. They view the new status $q u o$ as a win-win situation for Greece; yet from an instrumentalist perspective, if Turkey accepts the Copenhagen conclusions and fulfils the EU's requirements, then its behaviour towards Greece would be cooperative and accommodating. On the other hand, if Turkey chooses the path of escalation and refuses to comply with the EU's decisions over the Aegean and Cyprus disputes, then Turkey would have to face the European Union, rather than Greece alone. In 
contrast to this win-win situation for Greece's, if Turkey felt betrayed and frustrated the simultaneous Europeanisation processes in both countries would not take place (Dragoumis 2002).

The EU's positive treatment of Turkey, in light of the latest Turkish reforms undertaken by the current Justice and Development Party, such as limiting the number of generals in the National Security Council and improving the social, cultural and political rights of Turkey's Kurdish-origin citizens, may prove the most important turning point in Turkish-Greek relations in the years ahead. If the EU backs these reforms and makes clear its intention to start the accession talks with Turkey at the end of 2004, then Turkey's willingness to seriously contribute to the resolution of territorial problems with Greece, particularly the Cyprus dispute, within the EU framework would dramatically increase. The year 2004 will prove crucial for the future course of Turkish-Greek relations, and whether they can move from an instrumentalist into a sociological institutionalist approach.

\section{References}

Adamson, F.B. (2002) 'Democratisation in Turkey, EU Enlargement and the Regional Dynamics of the Cyprus Conflict', in: T. Diez (Ed.), The European Union and the Cyprus Conflict Modern Conflict and Post-modern Union (Manchester, Manchester University Press).

Bahcheli, T. (2000) 'Turkish Policy towards Greece', in: A. Makovsky and S. Sayari (Eds), Turkey's New World: Changing Dynamics in Turkish Foreign Policy (Washington, Washington Institute for Near East Policy).

Brauer, J. (2002) 'Survey and Review of Defense Economics Literature on Greece and Turkey: What We Have Learned?', Defense and Peace Economics, 13(2), pp. 85-107.

Brewin, C. (2003) 'A Changing Turkey: Europe's Dilemma', Journal of Southern Europe \& the Balkans, 5(2), pp. 137-46.

Buyukcolak, K.M. (2000) 'War of Projects: Turkish-Greek Rivalry in the Balkans in the Post-Cold War Period', Turkish Review of Balkan Studies, 12, pp. 131-39.

Cizre, U. (2003) ‘Demythologizing National Security Concept: The Case of Turkey', Middle East Journals, 57(2), pp. 213-30.

Cofoudakis, V. (1991) 'Greek Political Party Attitudes toward Turkey: 1974-1989', in: D. Constas (Ed.), The Greek-Turkish Conflict in the 1990s: Domestic and External Influence (London, Macmillan).

Couloumbis, T.A. (1990) 'Strategic Consensus in Greek Domestic and Foreign Policy Since 1974', in: V. Coufadakis, H.J. Posomosades and A. Gerolymatos (Eds), Greece and the New Balkans Challenges and Opportunities (New York, Pella).

Dakos, T.P. 2001. 'Greek Security Policy in the Twenty First Century', in: P.J. Tsakonas and A.D. Caratzos (Eds), Greece and Turkey after the End of the Cold War (New York, Christodoulos K. Yiallourides).

Dodd, C.H. (2000) 'Turkey and the Cyprus Question', in: A. Makovski and S. Sayari (Eds), Turkey's New World: Changing Dynamics in Turkish Foreign Policy (Washington, Washington Institute for Near East Policy).

Dragoumis, M. (2002) 'Athens, Nicosia in Win-Win Situation ... if They Play Their Cards Right', Athens News, 20 December, p. A99.

Duffield, J. (2002) 'What Are International Institutions', paper presented at the annual meeting of the International Studies Association, New Orleans, 24-27 March.

Efstathios, T.F. and Mavrides, P. (2001) 'Strategy of Crisis Management and the GreekTurkish Rivalry: The Case of the Imia Islets', in: P.J. Tsakonas and A.D. Caratzos (Eds), Greece and Turkey after the End of the Cold War (New York, Christodoulos K. Yiallourides).

Eralp, A. (2000) 'European Security and Turkey', Privateview, 8, pp. 52-55, < http:// www.tusiad.org $>$. 
Guvenc, S. (2000) 'Turkey's Changing Perception of Greece's Membership in the European Union: 1981-1998', Turkish Review of Balkan Studies, 12, pp. 102-29.

Heraclides, A. (2002) 'Greek-Turkish Relations from Discord to Détente: A Preliminary Evaluation', Review of International Affairs, 1(3), pp. 17-32.

Hickok, M.R. (1998) 'The Imia/Kardk Affair, 1995-96: A Case of Inadvertent Conflict', European Security, 7(4), pp. 118-36.

Hope, K. (2001) 'Greece and Turkey', Europe, 404, pp. 44-46.

Hope, K. (2002) 'Greek-Turkish Energy Deals', Europe, 417, pp. 44-47.

Ioakimidis, P.C. (1999) 'Greece, the European Union and Southeastern Europe: Past Failures and Future Prospects', in: V. Coufudakis, H.J. Psomiades and A. Gerolymatos (Eds), Greece and the New Balkans Challenges and Opportunities (New York, Pella).

Kramer, H. (1999) 'Turkey's Relations with Greece: Motives and Interests', in: D. Constas (Ed.), The Greek-Turkish Conflict in the 1990: Domestic and External Influence (New York, St Martin's Press).

Kuniholm, B. (2001) 'Turkey's Accession to the European Union: Differences in European and US Attitudes, and Challenges for Turkey', Turkish Studies, 2(1), pp. 25-53.

Larabee, F.S. and Lesser, I.O. (2003) Turkish Foreign Policy in an Age of Uncertainty (Santa Monica, CA, RAND's Center for Middle East Public Policy).

Manners, I. (2002) 'Normative Power Europe: A Contradiction in Terms?', Journal of Common Market Studies, 40, pp. 235-58.

Mearsheimer, J.J. (1990) 'Back to the Future Instability in Europe after the Cold War', International Security, 15(1), pp. 5-56.

Mearsheimer, J.J. (1994/95) 'The False Promise of International Institutions', International Security, 19(3), pp. 5-49.

Missiroli, A. (2002) 'EU-NATO Cooperation in Crisis Management: No Turkish Delight for ESDP', Security Dialogue, 33(1), pp. 9-26.

Mitrany, D.A. (1966) Working Peace System (Chicago, Chicago University Press).

Moustakis, F. and Sheehan, M. (2000) 'Greek Security Policy after the Cold War', Contemporary Security Policy, 21(3), pp. 95-115.

Oguzlu, H.T. (2002a) 'Turkey and the European Union: The Security Dimension', Contemporary Security Policy, 23(3), pp. 61-82.

Oguzlu, H.T. (2002b) 'The Clash of Security Identities: The Question of Turkey's Membership in the European Union', International Journal, Autumn, pp. 579-603.

Oguzlu, H.T. (2002c) 'Perennial Conflict or Everlasting Peace: The European Union's Involvement in Cyprus', Perception, 7(2), pp. 79-101.

Oguzlu, H.T. (2003) 'An Analysis of Turkey's Prospective Membership in the European Union from a "Security" Perspective', Security Dialogue, 34(3), pp. 285-99.

Oguzlu, H.T. (2004a) 'Changing Dynamics of Turkey's U.S. and EU Relations', Middle East Policy, 11(1), pp. 98-105.

Oguzlu, H.T. (2004b) 'The Impact of "Democratization along the EU accession process" on the Turkish Foreign Policy', Mediterranean Politics, 9(1), pp. 94-113.

Onis, Z. (2001) 'Greek-Turkish Relations and the European Union: A Critical Perspective', Mediterranean Politics, 6(3), pp. 31-46.

Papacosma, S.V. (1999) 'NATO, Greece, and the Balkans in the Post-Cold War Era', in: V. Coufudakis, H.J. Psomiades and A. Gerolymatos (Eds), Greece and the New Balkans Challenges and Opportunities (New York, Pella).

Papandreou, G.A. (2002) 'Greece's Foreign Policy in the 21st Century', Turkish Policy Quarterly, Spring, pp. 17-23.

Prusher, I.R. (1999) 'Role of Athens in Kurd Arrest May Hit Greco-Europe Ties', Christian Science Monitor, 91(58), p. 7.

Rumelili, B. (2003) 'Liminality and Perpetuation of Conflicts: Turkish-Greek Relations in the Context of Community-Building by the EU', European Journal of International Relations, 9(2), pp. 213-48.

Rumelili, B. (2004) 'Constructing Identity and Relating to Difference: Understanding the EU's Mode of Difference', Review of International Studies, 30(1), pp. 27-48.

Schimmelfennig, F. (2000) 'International Socialization in the New Europe: Rational Action in an Institutional Environment', European Journal of International Relations, 6(1), pp. 109-39. 
Schimmelfenning, F. (2001) 'The Community Trap: Liberal Norms, Rhetorical Action, and the Eastern Enlargement of the European Union', International Organization, 55(1), pp. 47-80.

Schimmelfennig, F. (2003) 'Strategic Action in a Community Environment', Comparative Political Studies, 36(1/2), pp. 156-83.

Siegl, E. 2002. 'Greek-Turkish Relations-Continuity or Change', Perspectives, 18, pp. 4052.

Smith, M.A. and Timmins, G. (2000) 'The EU, NATO, and the Extension of Institutional Order in Europe', World Affairs, 163(2), pp. 80-90.

Sjursen, H. (2002) 'Why Expand? The Question of Legitimacy and Justification in the EU's Enlargement Policy', Journal of Common Market Studies, 40(3), pp. 491-513.

Stivachtis, Y.A. (2002) 'Greece and the Eastern Mediterranean Region Security Considerations, the Cyprus Imperative and the EU Option', in: T. Diez (Ed.), The European Union and the Cyprus Conflict: Modern Conflict and Post-modern Union (Manchester, Manchester University Press).

Tsakonas, P.J. (2001) 'Post-Cold War Security Dilemmas Greece in Search of the Right Balancing Recipe', in: P.J. Tsakonas and A.D. Caratzos (Eds), Greece and Turkey after the End of the Cold War (New York, Christodoulos K. Yiallourides).

Tsakonas, P. and Tournikiotis, A. (2003) 'Greece's Elusive Quest for Security Providers: The "Expectations-Reality Gap" ', Security Dialogue, 34(3), pp. 301-14.

Tsoukalis, L. (1999) 'Greece: Like Any Other European Country?', National Interest, 55, pp. 65-75.

Turan, I. and Barlas, D. (1999) 'Turkish-Greek Balance: A Key in to Peace and Cooperation in the Balkans', East European Quarterly, 32(3), pp. 469-89.

Veremis, T. (1988) 'Greece and NATO: Continuity and Change', in: J. Chipman, (Ed.), NATO's Southern Allies: Internal and External Challenges (London, Routledge).

Waever, O. (1997) 'Insecurity, Security, and Asecurity in the West European Non-war Community', in: E. Adler and M. Barnett (Eds), Security Communities (Cambridge, Cambridge University Press).

Waltz, K. (2000) 'Structural Realism after the Cold War', International Security, 25(1), pp. $5-41$.

Winn, N. (2001) 'In Search of Europe's Internal and External Borders: Politics, Security, Identity and the European Union', Perspectives on European Politics and Society, 1(1), pp. 19-48.

Yiallourides, C.K. (2001) 'The External Policy Orientation of the Cypriot Republic', in: P.J. Tsakonas and A.D. Caratzos (Eds), Greece and Turkey after the End of the Cold War (New York, Christodoulos K. Yiallourides). 